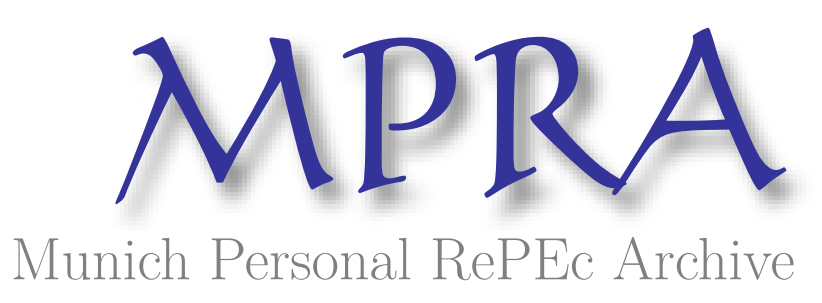

\title{
Global product as a result of globalization process
}

\author{
Wach, Krzysztof \\ Cracow University of Economics
}

2003

Online at https://mpra.ub.uni-muenchen.de/31660/

MPRA Paper No. 31660, posted 17 Jun 2011 19:36 UTC 


\section{Krzysztof WACH}

\section{GLOBAL PRODUCT AS A RESULT OF GLOBALIZATION PROCESS}

Summary: The paper elaborates on the process of global product creation. The author tries to define a global product. Basic product strategies on global market are described, among them: standardization, adaptation and diversification. Premises and conditions for product standardization as well as determiners of standardization and adaptation are quoted. Many examples of global product and its strategies are described.

Key words: global product, globalization, standardization, adaptation, product positioning

\section{Introduction}

Nowadays a belief that a new era has begun seems to be dominating international societies the time of globalizing political problems and above all economical ones is just beginning. There are obviously countless characteristics, such as cultural ones, that influence a particular nation `s radiation around the globe. However; observing the phenomenon taking place virtually in every aspect of life, one may see the overwhelming globalization process. During the past couple of years, integration processes and co-dependency as well as correlations in world economy have become more and more significant. Also the development of worldwide access to the Internet contributed to accelerate the globalization process. Due to the overwhelming globalization process in the world economy, a new type of product has appeared on the market. The global products these are available in the same form almost all over the world. The paper is going to present the global product as one of the results of the globalization process taking place in the world economy.

\section{Product standardization}

One of the main strategic decisions that a firm internationalizing its products must make is the degree to which it is going to standardize its products to particular markets. There are three basic strategies that can be noticed on the international market: standardization strategy, adaptation strategy and diversification strategy. Standardization is the entering of new markets (going global) with the virtually unchanged products. It allows the company to decrease the unit production cost as well as distribution and marketing costs. Moreover, standardization facilitates keeping the image of the company andlor product consistent. Adaptation strategy involves customising the product to requirements of new markets. Products are adapted mainly due to the cultural differences and various technical standards. Adaptation is a form midway through standardization and diversification. The diversification strategy includes offering distinct products on different national markets. The main disadvantage of this strategy is the high cost of implementation. The three types of product strategies on the international market are presented graphically on figure 1 . 
Figure 1. Product strategies on international markets

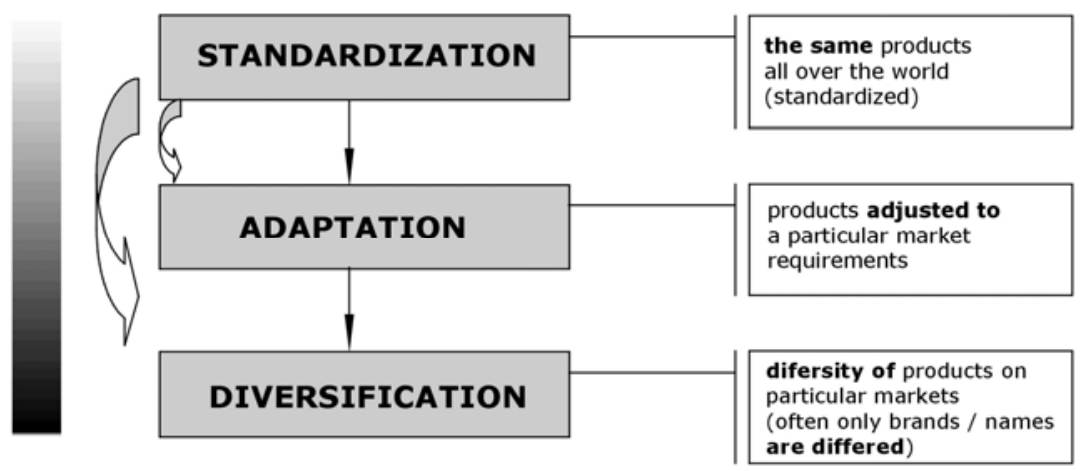

T.Levitt states that our world is becoming a common market, on which people regardless of the place they live in, desire the same products. The same lifestyle uniformity of consumer needs all over the world is the main stimulus for product standardization and globalization of the advertisement message. Requirements towards some product groups are standardized almost everywhere. Medicine products are a good example, as the majority of diseases are of a similar nature all over the world. Differences in culinary and diet trends are disappearing as well. So called oriental dishes became common in both Europe and America, whereas European dishes are widely available in Asia. Computers are another good example for high level global standardization of products. Their producers may easily standardize hardware as well as software. However, taking language differences and metric systems into consideration, one must mention that some elements of hardware and/or software should be adopted. The product standardization strategy might be used by organizations, if the conditions listed in table 1 are met.

Table 1. Conditions and premises for products standardizations

\begin{tabular}{|c|c|}
\hline 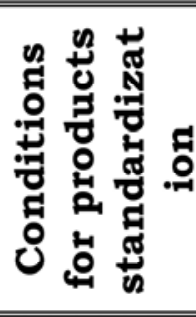 & $\begin{array}{l}\sqrt{ } \text { similar product material utylity on different markets because of its } \\
\text { characteristics } \\
\sqrt{ } \text { there is a possibility of creating of buyer`s preferences without } \\
\text { differenciating the product } \\
\sqrt{ } \text { there is a possibility to get adventages of scale, making the production on } \\
\text { both foreign and domestic market } \\
\sqrt{ } \text { low influence of the foreign markets on company`s activity } \\
\sqrt{ } \text { short life cycle of product } \\
\end{array}$ \\
\hline 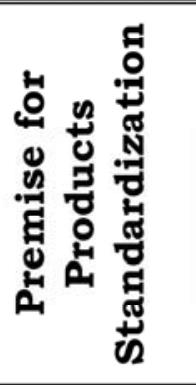 & $\begin{array}{l}\sqrt{ } \text { possibility of achieving adventages of scale, making the production line } \\
\text { longer reduces product's unit cost } \\
\sqrt{ } \text { savings in research and development funds, can be used for searching of a } \\
\text { new product, not for stisfing of the different preferences of the final } \\
\text { consumer } \\
\sqrt{ } \text { savings in promotion budget because of unifying of the strategy } \\
\sqrt{ } \text { flexibility of the consumers, possibility of buying products during trips } \\
\text { abroad, standardization influence on higher consumer`s loyalty } \\
\sqrt{ } \text { influences of the technology, services and spare parts are not causing } \\
\text { a problem for products standardization as the specifications are unified }\end{array}$ \\
\hline
\end{tabular}

Source: adopted from: R.Zembura (2000): Koncepcja produktu w marketingu międzynarodowym. Pomocnicze materiały dydaktyczne, AE, Kraków, pp.6-7 
The number of consumers (especially tourists) interested in standardized products increases on a monthly basis. Many clients, travelling around the world, buy chocolate as a gift or personal pleasure. Taste of chocolate can be easily influenced by adding local raw materials (such as macadamia nuts on the Hawaiian Islands or kiwi fruits in New Zealand), this phenomena also attracts travellers to purchase the product abroad. Voyagers come across various kinds of chocolate, which can set the global standards of its perceived quality and taste. For example the Poles prefer less sweet chocolate than consumers from Western Europe. Therefore foreign chocolate producers are expected to adjust their products to the local taste requirements. Many firms have experienced that not every product should be standardized, as some groups of products are dependent on customer tastes. The above mentioned Polish chocolate dilemma is a good example. Also Coca-Cola, in some African countries, needs to be less sweet and less sparking than the Coca-Cola sold on other markets. In Mexico McDonald's serves chilly souse instead of ketchup. Barbie doll is another good example. In Japan the toy was not accepted at first. The Japanese thought that the doll's legs were too long and her breasts were too big. As soon as

Table 2. Determiners of Standardization and adaptation

\begin{tabular}{|c|c|c|}
\hline & \multirow[b]{2}{*}{ Standardization } & \multirow[b]{2}{*}{ Adaptation } \\
\hline & & \\
\hline $\begin{array}{l}\text { Competition factor: } \\
\sqrt{ } \text { strong competition } \\
\sqrt{ } \text { market position }\end{array}$ & $\begin{array}{l}\text { weak } \\
\text { dominating }\end{array}$ & $\begin{array}{l}\text { strong } \\
\text { Non dominating }\end{array}$ \\
\hline $\begin{array}{l}\text { Market factor: } \\
\sqrt{ } \text { uniform of consumer's preferences } \\
\sqrt{ } \text { potential for growth small segments } \\
\sqrt{ } \text { purchase force of consumers } \\
\sqrt{ } \text { consumers willingness to pay for various } \\
\text { products } \\
\sqrt{ } \text { stisfied need by the product on the } \\
\text { operated markets } \\
\sqrt{ } \text { usage requirements }\end{array}$ & $\begin{array}{l}\text { homogeneous } \\
\text { low } \\
\text { equal } \\
\text { low } \\
\text { together with different } \\
\text { products } \\
\text { uniform }\end{array}$ & $\begin{array}{l}\text { heterogeneous } \\
\text { high } \\
\text { diversified } \\
\text { high } \\
\text { individual } \\
\text { various }\end{array}$ \\
\hline $\begin{array}{l}\text { Factors connected with products: } \\
\sqrt{ } \text { meaning of scale advantages in the } \\
\text { production } \\
\sqrt{ } \text { possibility of learning producing of } \\
\text { innovative products from small companies } \\
\sqrt{ } \text { kind of products } \\
\sqrt{ } \text { low regulations }\end{array}$ & $\begin{array}{l}\text { high } \\
\text { low } \\
\text { industrial } \\
\text { uniform }\end{array}$ & $\begin{array}{l}\text { low } \\
\text { high } \\
\text { commercial } \\
\text { various }\end{array}$ \\
\hline $\begin{array}{l}\text { Factors connected with company: } \\
\sqrt{ } \text { scope of involvement on international } \\
\text { market } \\
\sqrt{ } \text { Company resources } \\
\quad \text { (financial, human, productive) }\end{array}$ & $\begin{array}{l}\text { Big or limited on } \\
\text { many big markets }\end{array}$ & $\begin{array}{l}\text { Small or plentiful on } \\
\text { many small markets }\end{array}$ \\
\hline
\end{tabular}

Source: G.Albaum [ed.] (1994): International marketing and export management; Workingham, p.261 
Matel Toys executed adaptation strategy, the company accounted noticeable profits. Also Procter \& Gamble was forced to adapt their nappies to the Japanese market. The sizing was changed in order to adjust to tiny Japanese infants. A new colour scheme had to be introduced to go with baby's gender and the time of the day. The advertisement message was also transformed so as to stress the importance of the child's comfort. In Japanese culture, a reference to a mother's comfort is perceived to be contradicting the hierarchy of society's norms and values. Table 2 presents factors determining the choice between product standardization and product adaptation on international markets. The product element of the marketing mix allows the greatest level of standardization strategy implementation. Global firms might execute one of the four strategies concerning standardization and diversification resulting from product to brand relations ${ }^{1}$ :

- product and brand standardization (e.g. Sony, Agfa);

- product and brand diversification (e.g. Nestle);

- product standardization and brand diversification (e.g. Algida);

- product diversification and brand standardization (e.g. Danone).

There are various arguments in favour of product standardization: increasing product globalization, and thus formulating universal behaviour models on the global scale; establishment of a global firm or product image; lowering unit production cost. However, there are also arguments in favour of diversification and therefore, extension of production line by avoiding the problems arising from language and cultural differences (such as historical and ethnocentric indications). Brand name is also one of the global product's characteristics. It is one of the basic marketing tools. A good brand name facilitates entering new markets and maintaining the market position. In some cases it also becomes one of the firm's worth stimuli. A brand name is: "a name, a term, a symbol, a design or their amalgamation, created to identify goods and services of the seller in order to differentiate them from the competition" ${ }^{2}$. Expansion onto international markets requires making a decision as to whether the operation is going to be performed under the existing brand name or if there is a need to create a new brand name taking new markets into account. The conclusion should be based on the given brand recognition and position on the local market. Although brands such as McDonald's, Bosch, Siemens, or Fiat have a strong ethnical background, nobody considers changing them when entering new markets. Retaining an already established brand name is much cheaper than developing a new one. However, a change should be made if there is a general belief that the existing brand name will not perform its promotional function on new market well. This can happen if there is a lack of any connotations to the brand name on the grounds of given culture, making the message unclear or, even worse, it brings negative implications. Moreover, the brand name might be changed to modify the existing image of the company or the product in order to demonstrate their innovating nature. The adjustment of the name is quite often required as far as cultural differences are concerned. In this fashion, Opel changed the names of its makes from Kadet to Astra, and from Kapitan to Vectra ${ }^{3}$. General Motors, launching its Opel Astra onto the Japanese market, decided to change the name of the Astra make, as Astra was popular margarine in Japan. Rolls-Royce tried to promote its Mist on the German market, but in German the name means 'manure'. An American make Chevrolet Nova contained a hidden message for its Hispanic clientele, the brand name informed them that a car will not start (no va - means won't go in Spanish), also in Spanish ESSO means a "stalling

\footnotetext{
${ }^{1}$ M.Komar (2000), Euromarketing - Strategie marketingowe przedsiębiorstw na eurorynku, PWN, Warszawa, p.131

2 J.Altkorn (1999): Strategia marki, PWE, Warszawa 1999, p.11
} 
car" .7 up is another interesting example, it means "death through drinking" in one of the Chinese dialects..

Figure 2. Examples of standardization and diversification

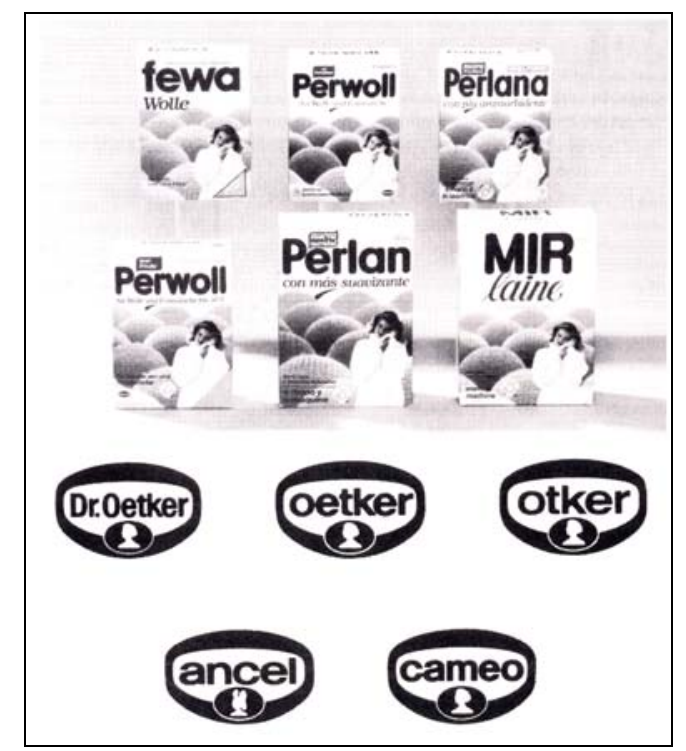

Source: S.Müller, M.Kornmeier (1995): Internationales Konsumguetermarketing [in:] A.Hermans, U.K.Wissmeier (ed.), Internationales Marketing Management: Grundlagen, Strategien, Instrumente, Kontrolle und Organization, Vahlem, München, pp.372-373

Some firms adopt the product name to existing language barriers. Such differentiation strategy is used by Jacobs Kraft Suchard as far as non-caffeine coffee is concerned. Depending on the market the product name varied: "Nuit et Jour", "Nacht und Tag" or "Night and Day". Mars also exercised a similar strategy for one of its products. Chocolate bar "Twix" changed its name to "Raider" in German-speaking countries. Currently, both companies standardize their product names into English in Europe ${ }^{5}$. Packaging, its size, texture, design, colour and writings should also be adapted. Elements of the sandardization and diversification strategiesing relation to products are demonstrated in the example of Dr. Oetker and Henkel (Figure 2). Henkel's products are relatively highly standardized, which enables their recognition. Only the name and the size of the products differ. A similar strategy was introduced by Dr. Oetker, the firm name was changed from country to country while the logo stayed the same so that the consumers would be able to recognize it right a way. At the beginning of 2001, an American weekly "Business Magazine" in cooperation with Interbrand Corp. presented a list of the top 100 best global brands based on the worth of a given brand. Table 4 demonstrates the top 10 of the world best brand names. Analyzing the date demonstrated below, one may see that durability of the brand name is not solely dependent on technological innovations. Consumers very often chose a particular product based on tradition; firm's established position on the market; and the quality of the product.

\footnotetext{
${ }^{5}$ A.Sznajder (1993): Sztuka promocji, Businessman Book, Warszawa, pp.218-227
} 


\begin{tabular}{c|l|c}
\hline Lp. & \multicolumn{1}{|c|}{ Brand Name } & $\begin{array}{c}\text { Brand Name } \\
\text { Value } \\
\text { (in mln USD) }\end{array}$ \\
\hline 1 & Coca-Cola & 68,1 \\
2 & Microsoft & 65,1 \\
3 & IBM & 52,8 \\
4 & General Electric & 42,4 \\
5 & Nokia & 35,0 \\
6 & Intel & 34,7 \\
7 & Disney & 32,6 \\
8 & Ford & 30,1 \\
9 & McDonald's & 25,3 \\
10 & AT\&T & 22,8 \\
\hline
\end{tabular}

Source: G.Khermouch, S.Holmes, M.Ihlwan (2001): The best global brands [in:] Businessweek Magazine, US Edition, August 6

\section{Global product}

In T.Levitt's opinion the future success of each firm will depend on its ability to create a global product. The term is not clearly defined in the references. Such products are not only available on the global market, but also are subject to the same or very similar promotion strategies on particular markets. Diversity of demand in those countries is an essential matter while discussing the issue. It is connected with the division of products into two groups: culture bound and culture free products ${ }^{6}$. The use and consumption of culture bound products, by their very definition are connected with cultural factors. Pork meat in Arabic countries and alcohol during Ramadan are the best example. In culture free products there is no such connection. Among them are cold drinks, cameras, snacks and computers. Those products were launched not so long ago, and thus no connection to cultural factors has yet been established. Moreover, global product should not only be available worldwide but it should also be of prime quality, resulting from systematic modification due to R\&D efforts, and should be priced attractively. Taking the range and global interests of producers into account, three groups of products can be distinguished:

- products headed towards local markets;

- products, with potential to perform on the global market;

- global products.

Products headed towards local markets are dedicated to customers with particular expectations and requirements. Among them are regional products (e.g. rural textiles and other traditional products) as well as products that are difficult to transport (e.g. bread, local agriculture products). The products of the second category have a potential to perform on the global market, but in such insignificant amounts that global firms are simply not interested in them. Here lies an opportunity for energetic small and medium sized firms to specialize in these products and therefore occupy, a so-called niche position. Authors researching global strategies agree that the products having

\footnotetext{
${ }^{6}$ A.Sznajder (1999): Euromarketing - Uwarunkowania na rynku Unii Europejskiej, PWN, Warszawa, p.126
} 
the greatest chance of reaching the global market are those that have a global brand name and have the following characteristics:

- are produced by well-known firms operating globally;

- have universal usefulness for a modern human being;

- can be widely accepted regardless of socio-cultural differences;

- have a cost advantage over competitors, which results form technical advantages;

- are of high quality;

- their market price can be accepted by consumers in various countries.

Figure 3. Global product creation process

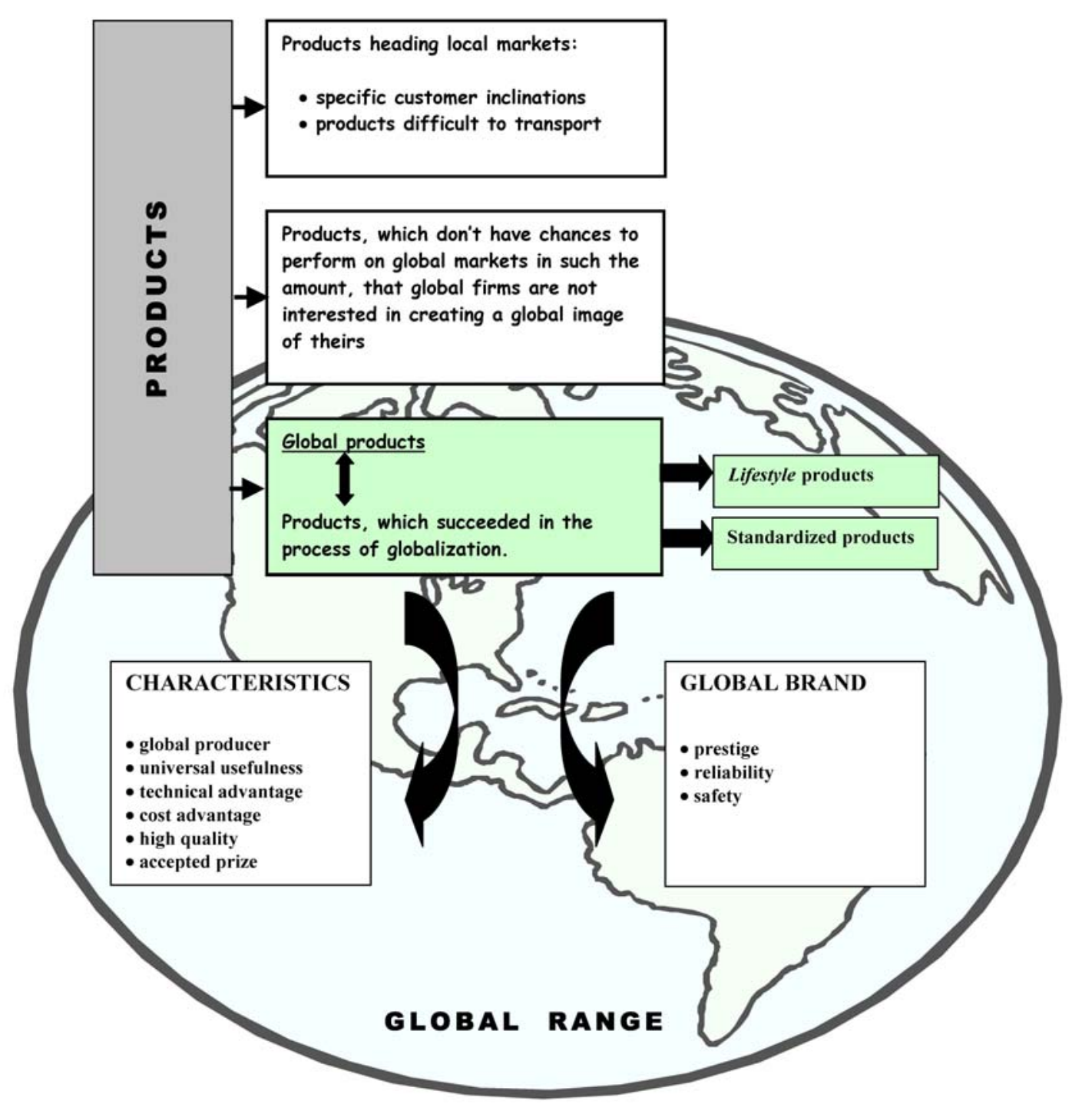


Products, which succeeded in the globalization process, can be divided into two categories ${ }^{7}$. The first group consists of products targeted to people leading the same life-style and having the same requirements regardless of their cultural background. Some examples of these are ready-to-wear clothes (Pret a Porter), Moet \& Chandon champagne, Porsche vehicles, classical music and the Financial Times. The second group is made up of the products that can be standardized and presented in the same form all over the world. These products are mostly bought by young consumers, who regardless of their cultural upbringing, consider themselves to be the citizens of the "global village". Good examples of such products are Coca-Cola drinks, the McDonald's chain, Levi's jeans, pop music, Colgate toothpaste, Sanyo TV sets, IBM computers, Wrigley's chewing gum and Marlboro cigarettes. There is a country of origin effect resulting from some products' brand names (e.g. American Coca-Cola, Levi's and McDonald's or French: Chanel and Dior) this helps to standardize the promotion message. The above described process of global product creation is shown in figure 3 .

\section{Global product positioning}

Product positioning is a modern way of advertising. The term is associated with marketing as well as strategic management. To position a product means to create its concept and its image in order to establish a specific connotation in the minds of customers. A firm wants to create such an image that will convince its target consumer to buy its products. Therefore, positioning is not about changing the product itself; it is about creating the image that seems to fulfil the needs of the client. Some elements of the product are changed so that the client will perceive it in a certain way. Products are positioned to: (1) gain a dominant position on the market; (2) extend brand image; (3) limit the existence of competitors on the market. Global product characteristics are worldwide recognition and unmatched quality. The quality results in unmatched functional value (such as durability, dependency and safety) as well as in securing clients' psycho-social needs (manifesting certain life-style, social status and ethnical belonging).. Research is currently being carried out to find the characteristics of a product that determine the creation of a global product and a global brand name. One of the famous concepts in this field, the continuum brand positioning model by T. Domzal and L. Unger is presented in figure 4.

The theory is based on the belief that there are groups of brand names, which are interconnected with so called engagement level. The combined attributes of either technical (high tech) or emotional nature (high touch) are the origin of global positioning. To the high tech products and brands one can account for machines and apparatus, cars, computers, audiovideo and other products requiring modern, sophisticated technologies. The group of high touch products consists of various goods. It includes products responding to universal needs such as cleanness (e.g. Colgate toiletries and cosmetics), entertainment (e.g. Swatch watches), as well as luxury products (e.g. Tiffany's jewellery, Armani clothing). Both groups, high-tech and high-touch products need a specific offering concept. It should meet consumers dreams about living their life in certain standards, brand name is promoted as a way to acquire the standard, or rather a life-style.

\footnotetext{
${ }^{7}$ H.Tendera-Właszczuk (2000): Cultural circumstances of advertisement on international markets [in:] J.Dad'o, J.W.Wiktor (ed), Marketing and globalization, Cracow University of Economics, Matel Bel University, CracowBanska Bystrica, p.325
} 


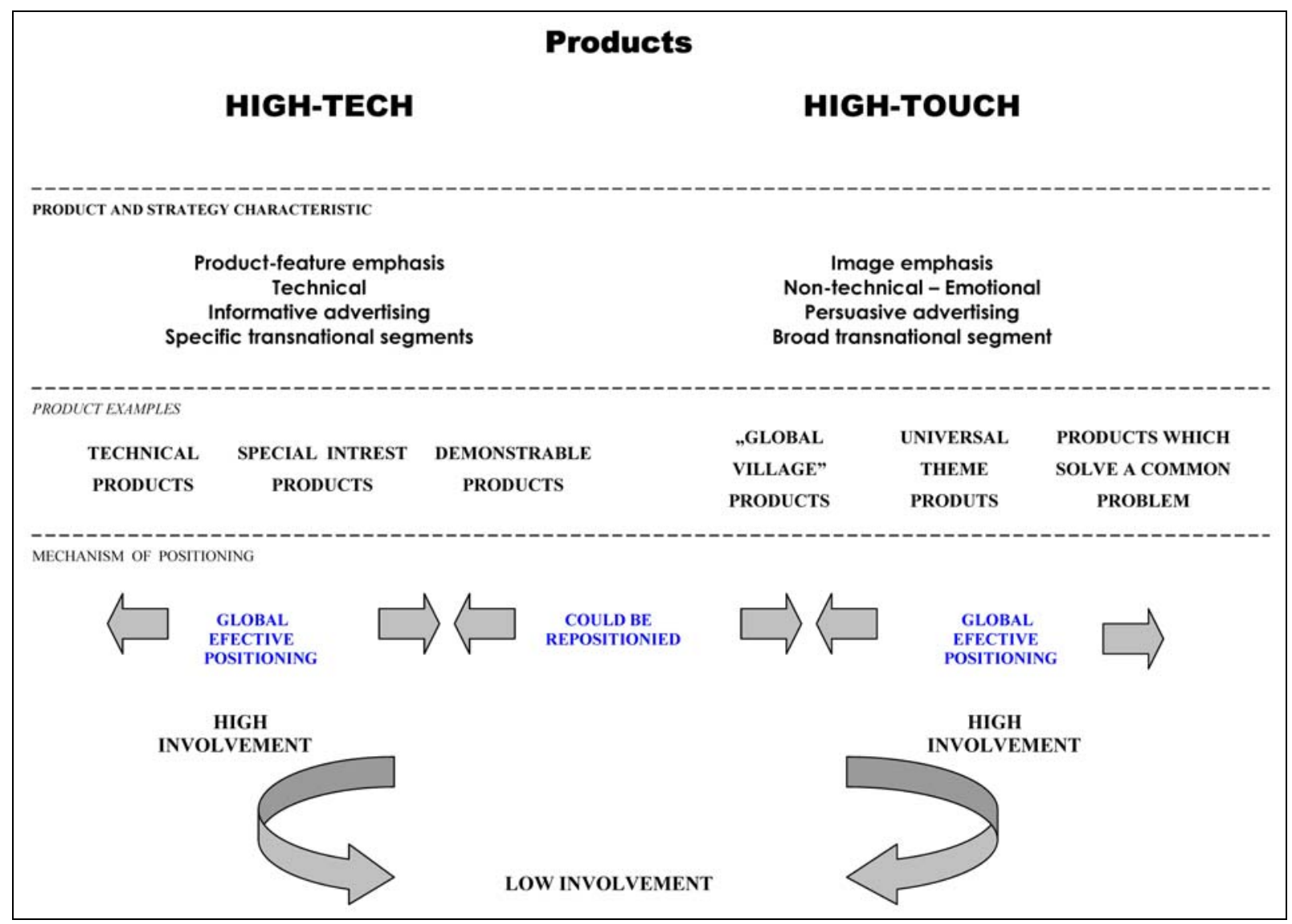

Source: T.Domzal. L.Uger (1987): Emerging positioning strategies in global marketing [in:] Journal of Consumer Marketing, vol.4, iss.4

\section{Conclusions}

As the idea of "global village" comes to life, life-styles and the way of thinking of people all over the world becomes similar. Parallel needs of the customers all around the globe is the main reason for standardization of products and services. Product standardization and the unification of consumer behaviour trends has brought about the creation of a new group of products - global products. As there is an increasing demand for global products, producers can standardize their offering. These goods are bought mainly by young people with cosmopolitan views. The globalization processes, taking place in the world economy, has a great impact on market unification, consumer needs unification and finally the unification of production. The global product group consists of: (1) high-tech products (e.g. computers, audio-video); (2) high-touch products (e.g. cosmetics, luxury jewellery and clothing); (3) universal products (e.g. cold drinks, cigarettes); and (4) specialized products (e.g. construction and medical equipment). The global product is definitely one of the effects of the globalization process as well the spread of a similar lifestyle demand resulting in similar requirements of clients all over the world. 


\section{Bibliography:}

1. Albaum G. (ed.), International marketing and export management; Workingham 1994

2. Altkorn J., Strategia marki, PWE, Warszawa 1999

3. Domzal T., Uger L., Emerging positioning strategies in global marketing [in:] Journal of Consumer Marketing, 1987, vol.4, iss.4

4. Khermouch G., Holmes S., Ihlwan M., The best global brands [in:] Businessweek Magazine 2001, US Edition, August 6

5. Komar M., Euromarketing - Strategie marketingowe przedsiębiorstw na eurorynku, PWAN, Warszawa 2000

6. Müller S., Kornmeier M., Internationales Konsumguetermarketing [in:] A.Hermans, U.K.Wissmeier (ed.), Internationales Marketing Management: Grundlagen, Strategien, Instrumente, Kontrolle und Organization, Vahlem, München 1995

7. Sznajder A., Sztuka promocji, Businessman Book, Warszawa 1993

8. Sznajder A., Euromarketing - Uwarunkowania na rynku Unii Europejskiej, PWN, Warszawa 1999

9. Tendera-Właszczuk H. (2000): Cultural circumstances of advertisement on international markets [in:] J.Dad'o, J.W.Wiktor (ed), Marketing and globalization, Cracow University of Economics, Matel Bel University, Cracow-Banska Bystrica

10. Zembura R. (2000): Koncepcja produktu w marketingu międzynarodowym. Pomocnicze materiały dydaktyczne, AE, Kraków 